\title{
ZBYSZKO MELOSIK
}

Uniwersytet im. Adama Mickiewicza

$w$ Poznaniu

\section{PIŁKA NOŻNA, AMERYKAŃSKI IZOLACJONIZM I PARADOKSY GLOBALIZACJI}

ABSTRACT. Melosik Zbyszko, Piłka nożna, amerykański izolacjonizm i paradoksy globalizacji [Soccer, American Isolationism and Paradoxes of Globalization]. Studia Edukacyjne nr 41, 2016, Poznań 2016, pp. 93-106. Adam Mickiewicz University Press. ISSN 1233-6688. DOI: 10.14746/se.2016.41.6

The article is devoted to analyzing the North American attitude towards soccer. American arguments against soccer are presented against the background of prevailing tendencies of world globalization. Also, the essence of soccer is confronted with the American version of masculinity, symbolized by aggressive American football.

Key words: soccer, globalization, isolationism, American football, masculinity

We współczesnych studiach kulturowych bardzo często podejmuje się problem roli Stanów Zjednoczonych w procesie globalizacji. W tym kontekście pojawiają się zwykle pojęcia amerykanizacji (ale także mcdonaldyzacji, czy coca-colizacji świata) ${ }^{1}$. Wobec tysięcy przejawów i dowodów amerykanizacji oraz "wysysania” świata z nośnych kulturowo oraz komercyjnie/konsumpcyjnie wartości i towarów, relacja Ameryki i piłki nożnej stanowi niezwykły fenomen.

Oto bowiem piłka nożna, która w przypadku wielu krajów jest integralną częścią tożsamości narodowej, a w takich jak Brazylia czy Argentyna wręcz tę tożsamość w dużym stopniu definiuje, w Stanach Zjednoczonych jest kwestionowana i odrzucana. „Piłka nożna jest wykluczona z definiowa-

\footnotetext{
${ }^{1} \mathrm{Na}$ ten temat por. Z. Melosik, Kultura popularna i tożsamość młodzieży. W niewoli władzy i wolności, Kraków 2013, s. 89-140.
} 
nia cech amerykańskiej tożsamości" 2 . Więcej nawet, wielu Amerykanów uważa, że piłka nożna stanowi zagrożenie dla tradycyjnych wartości amerykańskich i dominującego $\mathrm{w}$ tym społeczeństwie etosu. Tak pisze o tym w sposób jasny S. Whitsitt: „Być Amerykaninem i grać w piłkę są to więc dwie wyłączające się rzeczy. W piłkę nożną na pewno będzie grać się w Ameryce, ale to nie znaczy, że Ameryka będzie grać w piłkę". Amerykanie, którzy grają w piłkę nożną wychodzą poza "nasze dominujące kody kulturowe"; "oni są na marginesie i grają w niezdefiniowanej kulturowej przestrzeni" 3 .

Amerykanie krytykują również logikę/istotę piłki nożnej, przeciwstawiając ją amerykańskiemu footballowi. I tak S. Whitsitt uważa, że dla Amerykanów piłka nożna jest nudnym sportem, zbyt wolnym, który na dodatek często kończy się wynikiem bezbramkowym ${ }^{4}$. Ponadto,

wielu Amerykanów kpi z tego, że słabe drużyny piłkarskie często wygrywają, mimo iż niemal cały mecz koncentrują się wyłącznie na obronie (...), wyśmiewają się z tego, że jedna trzecia meczy kończy się remisem (ponieważ każdy mecz powinien zakończyć się zwycięstwem którejś z drużyn!) 5 .

Europejskie podejście do remisu, który niekiedy bywa uznawany wręcz za sukces, jest sprzeczne z podstawowymi przekonaniami Amerykanów na temat życia społecznego i własnej tożsamości (amerykański przeciwnik piłki nożnej stwierdził: ,jak jakikolwiek sport może być uważany za poważny, jeśli mecz kończy się remisem, niekiedy zero do zera"6).

Amerykanie nie potrafią zrozumieć istoty piłki nożnej, a w szczególności tego, że można w niej wykorzystywać nogi i głowę, ale dotknięcie piłki ręką jest surowo karane. Nie rozumieją również - o czym już wspomniano - że można koncentrować się $\mathrm{w}$ grze na defensywie; jest to sprzeczne $\mathrm{z}$ ich orientacją na atak7. Co ciekawe, wielu krytycznych wobec piłki nożnej Amerykanów nie pojmuje, dlaczego w piłce nożnej odlicza się czas od pierwszej minuty do dziewięćdziesiątej, a nie pokazuje na tablicy, ile minut zostało

2 L. Crolley, D. Hand, Football and European Identity. Historical Narratives Through the Press, London 2006, s. 166.

3 S. Whitsitt, Soccer: The game America refuses to play, Raritan, Summer 1994, 14, 1; dostęp autor uzyskał poprzez bazę danych EBSCO - w wersji html - bez stron.

${ }^{4}$ Tamże.

5 S. Szymanski, A. Zimbalist, National Pastime: How Americans Play Baseball and the Rest of the World, Washington 2005, s. 2.

6 J. McCain, 8 Reasons Why I Hate Soccer, w: sportowy portal internetowy "Go For 2", [dostęp: 30.05.2015]; adres internetowy: http:/ /goingfor2.com/8-reasons-why-i-hate-soccer/

7 J. Lever, Soccer Madness: Brazil's Passion for the World's Most Popular Sport, Long Grove, 2009, s. XVII. 
do końca meczu - czyli nie odlicza się od minuty dziewięćdziesiątej do pierwszej ${ }^{8}$.

Warto przytoczyć w tym miejscu kilka spektakularnych wypowiedzi, ilustrujących w sposób bardzo dobry stosunek Amerykanów do piłki nożnej. Oto S. Joyce pisze:

Baseball i football były powietrzem, którym oddychaliśmy od dnia urodzin. Nawet nie mogę sobie wyobrazić, że mógłbym pójść na mecz piłkarski ${ }^{9}$.

\section{Dolores Martinez zauważa:}

Jak Amerykanie mogliby preferować pozbawioną tempa, bez końca rytualną, sztywną grę, jaką jest piłka nożna, a nie prowadzoną w niezwykle szybkim tempie, wymagającą niezwykłych kompetencji, brutalnie piękną i nieustannie urzekającą grę jaką jest prawdziwy [amerykański] football?10.

\section{Z kolei amerykański komentator sportowy stwierdził:}

Mój syn nie będzie grał w piłkę nożną (...) To nie jest sport.

Inny konserwatysta Glenn stwierdził podczas mistrzostw świata w roku 2010 (w USA):

Nie ma znaczenia, w jaki sposób próbuje nam się to sprzedać... Nie chcemy mistrzostwa świata, nie akceptujemy mistrzostw świata, nie lubimy piłki nożnej, nie chcemy z nią mieć nic wspólnego ${ }^{11}$.

Uważa się także, że piłka nożna podmywa tradycyjny amerykański etos:

Jak (...) weganizm (...) piłka nożna jest wirusem, rozprzestrzeniającym się w miastach amerykańskich, uderzającym w ten kraj i jego ducha ${ }^{12}$.

8 S. Joyce, The Top Ten Reasons to Hate Soccer, w: sportowy portal internetowy „bleacher report", http://bleacherreport.com/articles/164778-the-top-ten-reasons to-hate-soccer/page/2, [dostęp: 29.04.2009].

9 Tamże.

${ }^{10}$ D. Martinez, Soccer in the USA: 'holding out for a hero'? Soccer and Society, April 2008, 2, 2, s. 231.

11 A.M. Lindner, D.N. Hawkins, Globalization, Culture Wars, and Attitudes Toward Soccer in America: An Empirical Assessment of How Soccer Explains the World, The Sociological Quarterly, 2012, 53, s. 69-70.

$12 \mathrm{~J}$. Winkler, "Soccer" is a virus invading America. Where are all the rowdt football fans? "The Guardian" z 26.04.2014; adres internetowy: https://www.theguardian.com/commentisfree/ 2014/jun/24/soccer-america-football-fans-world-cup-fever 
I jeszcze jeden przykład spektakularnej krytyki piłki nożnej przez Amerykanów, dobrze ilustrujący podejmowany tutaj problem:

Piłka nożna jest nudna (...) Od grania w nią gorsze jest jedynie jej oglądanie (...) Jeśli oglądasz mecz piłkarski w telewizji i w jego trakcie pójdziesz na dłuższy spacer, to gdy siądziesz z powrotem, szybko zrozumiesz, że nic się nie wydarzyło.

Autor cytowanego tekstu nie może zaakceptować wyniku „zero-zero”.

Jestem Amerykaninem. Uwielbiam, jak na boisku zdobywa się punkty. Uwielbiam akcje (...). W piłce nożnej bramki są (...) rzadkością, a gdy zespół prowadzi dwoma, trzema bramkami, to już jest jakby koniec meczu (...) Mówiąc inaczej: w piłce nożnej nie ma tego, co jest najlepsze w przy kibicowaniu - nagłych zwrotów akcji (...) $\mathrm{W}$ piłce nożnej ma miejsce ogromne inwestowanie wysiłku przy braku niemal jakichkolwiek zysków ${ }^{13}$.

Niektórzy komentatorzy recepcji piłki nożnej w Stanach Zjednoczonych podkreślają nawet, iż amerykański sceptycyzm wobec niej stanowi integralną część „wojny kulturowej”, jaką Ameryka prowadzi ze „starą Europą". Konserwatysta Tom Piatak napisał: „Piłka nożna to system metryczny w krótkich spodenkach". Wzywał on do odrzucenia przez Stany Zjednoczone zarówno piłki nożnej, jak i systemu metrycznego, pisząc:

Nie chcę patrzeć, jak Ameryka się globalizuje, i to samo dotyczy sportu amerykańskiego $^{14}$

(warto w tym miejscu dodać, że zdaniem Davida Riesmana i Reuela Denneya również i rugby zostało przez Amerykę odrzucone, bowiem symbolizuje ono dziedzictwo brytyjskiej klasy wyżej; podobnie piłka nożna symbolizuje „starą Europę"15). Allen Barra, dziennikarz sportowy dla „Wall Street Journal" stwierdził:

Tak, piłka nożna jest najbardziej „popularnym” sportem na świecie. A ryż jest najbardziej "popularnym” jedzeniem na świecie. I co z tego? Może gdyby inne kraje mogły pozwolić sobie na ligi footbolowe, koszykarskie czy basebolowe (...) preferowałyby te sporty nad piłkę $e^{16}$

13 S. Moore, Why American (rightly) hate the soccer, "The Daily Signal" z 26.06.2014; http:/ / dailysignal.com/2014/06/26/world-cup-isnt-everyone/

${ }_{14}$ A.M. Lindner, D.N. Hawkins, Globalization, Cultural Wars, s. 68.

15 T. Collins, Unexceptional exceptionalism: the origins of American football in a transnational context, Journal of Global History, July 2013, 8, 2, s. 209, 210, spr XXX.

${ }^{16}$ F. Foer, How Football Explains the World, London 2004, s. 236. 
(oczywiście ligi koszykówki istnieją w bardzo wielu krajach, o czym tenże dziennikarz zdaje się nie wiedzieć). Inny komentator stwierdził wręcz patetycznie:

Piłka nożna jest sportem europejskim. Nie po to wywalczyliśmy niepodległość w roku 1776, aby zobaczyć, jak nasz wspaniały naród ekscytuje się tym sportem ${ }^{17}$.

W kontekście powyższych rozważań wyłania się bardzo ciekawa teza dotycząca postrzegania w Ameryce procesu globalizacji: oto cały świat uważa, że stanowi on nośnik amerykanizacji, z kolei część Amerykanów sądzi, że grozi ona integralności tego kraju i wymazuje tradycyjne wartości amerykańskie.

Inny powód sceptycyzmu Amerykanów wobec piłki nożnej wynika z faktu, iż kraj ten - przynajmniej obecnie - nie ma większych szans, aby uzyskiwać w tej dyscyplinie znaczące sukcesy. Piłka nożna nie jest atrakcyjna dla Amerykanów, ponieważ nie są w tym najlepsi18. O ile przy tym najlepsi koszykarze czy hokeiści na lodzie z Europy marzą o grze w amerykańskich zespołach zawodowych, to w przypadku piłki nożnej jest odwrotnie: najlepsi Amerykanie marzą o grze w Anglii, Niemczech, Włoszech lub w Hiszpanii. To bardzo mocno uderza w wizerunek piłki nożnej w Stanach Zjednoczonych ${ }^{19}$. Amerykańska piłka nożna oparta głównie na zachodnioeuropejskich (często niemalże emerytowanych) gwiazdach musi być postrzegana przez aroganckich Amerykanów jako „obca”, a nie „nasza”20.

Tak pisze o tym Steven Moore:

Jesteśmy w Ameryce, światowym mocarstwie ekonomicznym i politycznym, najbogatszym miejscu na tej planecie. I jest kuriozalne, że nasze szanse na zdobycie mistrzostwa świata w piłce nożnej wynoszą jeden procent. A baseball to jest prawdziwy sport. I jesteśmy w nim bezdyskusyjnie najlepsi na świecie (...) Biorąc pod uwage problemy ekonomiczne w Ameryce, ofensywy ISIS w Iraku czy coraz to nowsze skandale, z którymi musi się borykać Biały Dom, potrzebujemy spektakularnego sukcesu. Mistrzostwa świata $\mathrm{z}$ pewnością nie dadzą nam tego - zostawmy je więc Niemcom i Brazylii21.

W tym kontekście przeciwstawia się w Stanach Zjednoczonych piłce nożnej amerykański football (który oprócz koszykówki, baseballu i hokeju

\footnotetext{
17 J. McCain, 8 Reasons Why I Hate Soccer.

18 A.S. Markovits, S.L. Hellerman, Offside: Soccer and American Exceptionalism, Princeton

${ }^{19}$ Tamże.

${ }^{20}$ M. Veseth, Globaloney 2.0: The Crash of 2008 and the Future of Globalization, Plymouth 2010,

21 S. Moore, Why American (rightly) hate the soccer.
} 2001, s. 160 . s. $115-116$. 
na lodzie jest najpopularniejszym sportem w tym kraju). Uważa się, że football - w przeciwieństwie do piłki nożnej (odróżnionej od niego w Stanach Zjednoczonych przez pojęcie soccer) - uosabia istotę czy esencję kultury amerykańskiej.

Warto przedstawić kilka wybranych kontekstów tego problemu. I tak, football wpisuje się w amerykańską ideologię dominującej męskości. Wiele amerykańskich badań z lat 1920-1960 wykazuje, że gracze futbolu amerykańskiego byli postrzegani przez amerykańską opinię publiczną - przez osoby obu płci - za najbardziej męskich. Do dziś zdają się stanowić esencję męskości w tym kraju ${ }^{22}$. Są uważani za mężczyzn typu alfa. Uważa się przy tym, że futbol ustanowił standardy, względem których oceniana była męskość młodych mężczyzn ${ }^{23}$. Mężczyzna-futbolista stanowił zawsze jedną część dychotomii, na której drugim biegunie znajdowała się kobieta lub zniewieściały mężczyzna. Była to jedna z odpowiedzi na kryzys męskości, a jej przejawem była także obecność na stadionie podczas meczów futbolowych młodych uroczych dziewcząt i radosnych, wystrojonych cheerleaderek, które miały potwierdzać ultra-męskość futbolistów ${ }^{24}$. Podobnie problem ten ujmuje Eric Anderson, uważając, że przez cały dwudziesty wiek męskie sporty zespołowe służyły w Stanach Zjednoczonych do promowania „konserwatywnej formy męskości", heteroseksualnej, dominującej, często zorientowanej na przemoc. Miała ona stanowić antidotum na feminizację męskości, represjonować męskie lęki i ból fizyczny ${ }^{25}$. Historia amerykańskiego baseballu, footballu, koszykówki, czy hokeja na lodzie jest pełna epokowych, legendarnych nazwisk, które symbolizują, co to znaczy być „amerykańskim mężczyzną"; wyrażają „wyidealizowaną konstrukcję narodowej męskości"26.

Występuje tu przy tym, zdaniem Michaela Oriarda, pewna tautologia:

Gracze futbolowi byli uważani za najbardziej męskich mężczyzn, ponieważ uprawiali futbol, który stanowił najbardziej męski sport, ponieważ był uprawiany przez najbardziej męskich mężczyzn²7.

22 M. Oriard, King Football: Sport and Spectacle in the Golden Age of Radio and Newsreels, Movies and Magazines, the Weekly and Daily Press, North Carolina 2001, s. 328.

23 Tamże, s. 329.

${ }^{24}$ Tamże; na temat kryzysu męskości por. Z. Melosik, Kryzys męskości w kulturze wspótczesnej, Kraków 2006.

25 E. Anderson, Inclusive masculinities of university soccer players in the American Midwest, Gender and Education, 2011, 23, 6, s. 730.

${ }^{26}$ D. Martinez, Soccer in the USA, s. 235.

${ }_{27}$ M. Oriard, King Football, s. 357. 
Dolores Martinez pisze:

życie heroicznych graczy stanowi kluczowy element definiujący narracje konstruujące narodowej męskości ${ }^{28}$.

Tradycyjnie przy tym w amerykańskich szkołach piłka nożna była postrzegana jako sport dla dziewcząt, albo tych chłopców, którzy nie mogą poradzić sobie $\mathrm{w}$ poważnych amerykańskich sportach, jak: football, koszykówka, baseball, hokej na lodzie, a nawet zapasy ${ }^{29}$. Jeden z trenerów footballu amerykańskiego zwykł mówić do swoich zawodników: „Jeśli nie potrafisz rzucić się na przeciwnika, graj w piłkę nożną" 30 . W Ameryce oskarża się wręcz piłkę nożną o feminizację mężczyzn (z kolei, w pewnym paradoksie, w Europie podnoszone są głosy oskarżające Amerykę o feminizację piłki nożnej - a to z uwagi na jej popularność wśród dziewcząt i kobiet).

Poza tym, football znakomicie wpisuje się w amerykańską orientację na osiągnięcia i sukces, a przede wszystkim - absolutyzację kategorii zwycięstwa. Football amerykański uosabia mentalność typu „liczy się tylko zwycięstwo" (lub „zwycięzca bierze wszystko"). Celem uczestnictwa Amerykanów w sporcie jest wygrana; grają po to, aby wygrać, a nie po to, aby zremisować. Jedna $z$ najbardziej znaczących postaci w historii futbolu amerykańskiego (gracz, trener i działacz) Vince Lombardi stwierdził: „zwycięstwo nie jest wszystkim, zwycięstwo jest jedynym co istnieje" 31 . Twierdzi się przy tym, że w okresie społecznych kryzysów i niepokojów „football dostarcza Amerykanom płaszczyzny identyfikacji". Na boisku pojawiają się, nawiązujący do stabilnych i uregulowanych, dawnych czasów, "prawdziwi mężczyźni", którzy przejawiają atawistyczne instynkty walki ${ }^{32}$. Można przytoczyć w tym miejscu jeszcze podobne poglądy, jakie wygłaszają Gerald R. Gems i Gertrud Pfister:

football (...) stanowi wytwór i motor amerykańskości (...) Symbole, rytuały i znaczenia inherentne dla tej gry są związane z jasną definicją Stanów Zjednoczonych jako agresywnej, skomercjalizowanej i patriarchalnej kultury, gotowej do promowania swoich ideałów na poziomie świata 33 .

28 D. Martinez, Soccer in the USA, s. 239.

29 Tamże, s. 234.

30 D. Risolo, Soccer Stories: Anecdotes, Oddities, Lore, and Amazing Feats, University of Nebrasca 2010, s. 210.

31 G.R. Gems, G. Pfister, Understanding American Sports, Abingdon 2009, s. 148.

32 Tamże, s. 150.

33 Tamże. 
Nic więc dziwnego, że podkreśla się, iż rozwój amerykańskiego futbolu szedł w parze z rozwojem Stanów Zjednoczonych jako potęgi światowej34.

Amerykański futbol ma jasne związki z amerykańskim militaryzmem. Piszą o tym w sposób następujący Joel F. Cassman i David Lai:

Od swoich początków w końcu dziewiętnastego wieku amerykański football stanowi paradygmat dla amerykańskiego sposobu prowadzenia wojny. Football jest głęboko zakorzeniony w amerykańskiej mentalności współzawodnictwa.

Ten ostatni podkreśla, że posiada on takie atrybuty, jak konflikt, szybkość, siłę, spektakularność i orientację na uzyskanie rezultatu, a także takie cechy, jak dyscyplina, praca zespołowa i odwaga w obliczu niebezpieczeństwa ${ }^{35}$.

Amerykański futbol jest unikatowy w tym sensie, że jest dyscypliną opierającą się na ogromnej dawce przemocy z jasnymi zasadami postępowania. Bardzo ważną rolę podobnie, jak podczas działań militarnych - odgrywa tutaj terytorium, nad którym każdy zespół usiłuje uzyskać kontrolę. W grze uzyskuje się zwykle wysokie rezultaty punktowe, a jej istotą są nieustanne ataki ${ }^{36}$.

W konkluzji tego fragmentu rozważań można przytoczyć przekonanie Gerharda Falka, że amerykański football:

włącza te wszystkie wartości, które czyni społeczeństwo amerykańskie unikatowym $^{37}$; stanowi on wyraz systemu kapitalistycznego, na którym opiera się nasza wolność38.

Według tego samego autora uosabia on wartości kultury WASP (Białych Protestantów pochodzenia Anglosaskiego) i zawiera w sobie

wiele z podstawowych kodów, które determinują sposób, w jaki Amerykanie pojmują zarówno samych siebie, jak i swoją kulturę 39 .

Istnieje przy tym pewien paradoks, oto bowiem najlepszymi graczami $\mathrm{w}$ footballu amerykańskim są czarni i nie należący do WASP, jednakże sam football jest produktem przekonań i postaw Białych ${ }^{40}$.

34 J.F. Cassman, D. Lai, Football vs. Soccer. American Warfare in an era of unconventional threats, Armed Forces Journal, November 2003, s. 50.

35 Tamże.

36 Tamże.

${ }^{37}$ G. Falk, Football and American Identity, Binghamption 2005, s. 1.

38 Tamże, s. 4.

${ }^{39}$ S. Whitsitt, Soccer: The game.

${ }^{40}$ Tamże. 
Wracając do problemu rozwoju piłki nożnej w Stanach Zjednoczonych, można stwierdzić, że mamy tam $\mathrm{w}$ jej ramach do czynienia $\mathrm{z}$ jej paradoksalną polaryzacją. Wiele milionów ludzi gra w nią rekreacyjnie, jednakże bardzo niewielu tworzy grupę „profesjonalnych fanów”, interesujących się wynikami meczów ${ }^{41}$. Warto zwrócić $\mathrm{w}$ tym miejscu jednak uwagę na pewien paradoks. Oto bowiem, o ile piłka nożna jest sportem międzynarodowym, absolutnie globalnym, wzbudzającym ogromne zainteresowanie na całym świecie, to najpopularniejsze sporty amerykańskie (z wyjątkiem koszykówki) są fenomenami regionalnymi. Więcej jeszcze, Amerykanie nie mają żadnych ambicji, aby stały się one globalne.

Warto przytoczyć w tym kontekście dłuższy fragment rozważań Michiko Hase:

Jeden z paradoksów amerykańskiego stylu życia polega na relatywnym braku zainteresowania światem poza Stanami Zjednoczonymi i to niezależnie od tego, że posiadają one ogromną władzę ekonomiczną, militarną i kulturową w świecie. Można argumentować, że Amerykanie mogą pozwolić sobie (...) na obojętność wobec reszty świata właśnie z powodu swojej hegemonicznej pozycji. To samo dotyczy sportu: Stany Zjednoczone stanowią „najbardziej wyizolowaną sportową kulturę na świecie" 42 .

Dla Amerykanów najważniejszym układem odniesienia jest więc w dziedzinie sportu Ameryka. Wydaje się, że przynajmniej w sferze najpopularniejszych sportów nie potrzebują oni sukcesów zewnętrznych. Dotyczy to zarówno footballu, jak i hokeja, baseballu oraz koszykówki, w przypadku których rozgrywki wewnętrzne mają dla Amerykanów znacznie większe znaczenie niż międzynarodowe.

Ciekawe, że dotyczy to także wymienionej wyżej koszykówki, która jako jeden $\mathrm{z}$ najbardziej popularnych sportów ma charakter zdecydowanie międzynarodowy (pod względem popularności zajmuje ona drugie miejsce w świecie). Większość Amerykanów interesuje się koszykówką wyłącznie na poziomie amerykańskim ${ }^{43}$. Przeciwnie niż Europejczycy, Amerykanie nie postrzegają $\mathrm{w}$ tej dyscyplinie swojego uczestnictwa $\mathrm{w}$ zawodach na poziomie międzynarodowym, w kategoriach "obowiązku”, ,"honoru”, czy "przywileju". Mistrzostwa świata w koszykówce są niemal niedostrzegane w Sta-

${ }^{41}$ A.S. Markovits, L. Rensmann, Gaming the World. How Sports are Reshaping Global Politics and Culture, Woodstock 2010, s. 129.

${ }^{42}$ M. Hase, Race in Soccer as a Global Sport, [w:] Sports Matters. Race, Recreation and Culture, red. J. Bloom, M.N. Willard, New York 2002, s. 313.

${ }^{43}$ A.S. Markovits, S.L. Hellerman, Offside: Soccer and American, s. 47. 
nach Zjednoczonych, gdzie zainteresowanie skoncentrowane jest na lidze zawodowej NBA oraz zawodach amatorskich na poziomie koledżów ${ }^{44}$.

Warto przytoczyć w tym miejscu tezę, którą stawia Sandra Collins:

O ile piłka nożna rozwija w sposób znaczący narodowe sentymenty i tożsamości, to jednocześnie jednak oferuje międzynarodowy język komunikacji i międzynarodowy kod kulturowy, który jest rzeczywiście integrujący (...) Żaden z hegemonicznych sportów amerykańskich nie oferuje takich sentymentów. Amerykańskie sporty ani nie są źródłem głębokiego poczucia nacjonalizmu, ani nie dostarczają prawdziwego forum dla umiędzynarodowienia. One są zawarte w swoim własnym świecie ${ }^{45}$.

Tak więc można stwierdzić, że sporty te stanowią dla Amerykanów zarówno płaszczyznę izolacjonizmu, jak i źródło poczucia wyższości. Wychodzą z założenia, że i tak są $\mathrm{w}$ nich najlepsi na świecie, nie ma więc nawet potrzeby konfrontowania się z drużynami z innych krajów.

W kontekście potencjalnej ważnej roli amerykańskiej piłki nożnej $\mathrm{w}$ świecie warto dodać, że jest ona zdecydowanie kwestionowana przez Europejczyków.

Niczego bardziej nie obawiają się kibice piłki nożnej w Europie, jak tego, że mistrzostwa świata wygrałby narodowy zespół Stanów Zjednoczonych (...), co oznaczałoby, że nawet $\mathrm{w}$ świecie piłki - jednej z kluczowych sfer potwierdzających zakładaną wyższość Europy nad Ameryką - ta druga stała by się super-władzą ${ }^{46}$.

A zwycięstwo amerykańskiego zespołu narodowego na MŚ w 1950 nad drużyną angielską jest uznawane w Europie za największą "obrazę" w historii piłki nożnej. Anglia - kolebka piłki nożnej - została pokonana przez kraj, który na mapie piłkarskiej świata traktowany był niemal jak Antarktyka ${ }^{47}$.

Kiedy jeden z trenerów niemieckiej kadry narodowej Jürgen Klinsmann sprowadził ze Stanów Zjednoczonych grupę ekspertów specjalizujących się $\mathrm{w}$ ocenie różnych parametrów przygotowania sportowców (np. w zakresie wydolności, przyspieszenia), to decyzja ta została w Niemczech przyjęta bardzo sceptycznie:

Przyjęcie rad od ekspertów holenderskich, włoskich, nawet francuskich, osób z wiodących krajów piłkarskich, którym zdarzało się pokonać Niemcy mogło być akceptowalne. Ale z pewnością nie od Amerykanów. Cóż mogli oni wiedzieć o piłce noż-

44 Tamże.

45 S. Collins, National Sports and Other Myths: The Failure of US Soccer, Soccer and Society, 2006, 7, 2-3, s. 358.

46 A.S. Markovits, L. Rensmann, Gaming the World, s. 142.

${ }^{47}$ D. Risolo, Soccer Stories, s. 170. 
nej? Ich zatrudnienie stanowiło zniewagę dla niemieckiej kultury piłki nożnej i jej know-how ${ }^{48}$.

Znakomity piłkarz niemiecki Paul Breitner, już w roli dziennikarza gazety „Bild”, stwierdził bez ogródek: „Amerykanie mogliby pracować z powodzeniem w takich amerykańskich dyscyplinach, jak football, baseball czy koszykówka", dodając, że te sporty nie mają nic wspólnego z "naszą piłką nożną" 49 . Dodam, że w konsekwencji małej popularności piłki nożnej w Ameryce, wybór Stanów Zjednoczonych na miejsce mistrzostw świata w 1994 roku postrzegany był jako „ekscentryczny” 50 .

Na zakończenie warto powrócić do relacji między piłką nożną i globalizacją. I tak, mogę stwierdzić, że jeszcze w niedalekiej przeszłości w amerykańskiej polityce kulturowej dominowała „ciężka” wersja amerykanizacji: rzeczywiście świat miał wyglądać jak Ameryka. Mówiąc metaforycznie (i ironicznie): „każdy wszędzie” miał preferować hamburgera z McDonald's nad swoje lokalne tradycyjne potrawy, słodką coca-colę nad swoje lokalne napoje, dżinsy Levisa nad własne stroje ludowe, palić papierosy Marlboro, a ostatecznie preferować język angielski nad rodzimym. W takim podejściu świat, zarówno ten zachodni, jak i ten egzotyczny, miał stać się częścią Ameryki. W inwazyjnie przeprowadzanym "kulturowym marketingu" próbowano narzucić światu wersję standardowo marketingowanej Ameryki. Wulgarna, wojownicza wersja amerykanizacji, którą uosabiał Rambo oraz cheeseburger z McDonald's i atrakcyjna puszka coli nie sprawdziła się wymazanie lokalnych kultur i zastąpienie kulturą amerykańską nie było możliwe. Świat nie stał się częścią Ameryki.

Bardziej „miękką" wersję amerykanizacji stanowi przekształcenie narodowych czy etnicznych kultur lub popularnych w świecie praktyk kulturowych (w tym także dyscyplin sportowych czy form sztuki) w odmiany kultury amerykańskiej. Ubezwłasnowolnianie i wymazywanie lokalnych kultur przez Amerykę można opisać w sposób następujący. Oto, amerykańskie mass media i kultura popularna przechwytują atrakcyjne i popularne praktyki kulturowe, a następnie nasycają je amerykańskimi „wartościami” - klimatem i kolorytem po to, aby eksportować je zwrotnie - w wersji zamerykanizowanej/skomercjalizowanej na cały świat (na przykład chińskie lub koreańskie restauracje powstające w Europie są zwykle kopią amerykań-

${ }^{48}$ R. Honigstein, Das Roboot. How German Football Reinvented Itself and Conquered the Wolrd, London 2015, s. 55-56.

49 Tamże, s. 56.

50 S. Redhead, Baudrillard, "Ame'rique", and the Hypereal World Cup, [w:] Sport and Postmodern Times, red. G. Rail, Albany 1998, s. 227. 
skich reprezentacji tych kuchni, podobny charakter ma skomercjalizowana produkcja etnicznych stylów muzycznych). W rezultacie, mieszkańcy różnych, kulturowo odmiennych zakątków świata otrzymują - poprzez globalne mass media - obraz swoich praktyk kultur i samych siebie; już przetworzonych marketingowo (zgodnie $\mathrm{z}$ ideologią konsumpcji), z domieszką „amerykańskiego marzenia”. W konsekwencji, partykularne społeczeństwa i kultury zaczynają patrzeć na siebie oczyma Amerykanów.

W takiej logice myślenia mogę stwierdzić, iż amerykański korporacyjny globalizm stara się przejąć ze świata wszystko to, co jest ekscytujące, co nowe i świeże, co może mieć wartość w ofercie gotowych do spożycia atrakcyjnych i przyjemnych wrażeń. Odmienne praktyki kulturowe są tutaj traktowane tylko jako „wstępne tworzywo”, podatne na niemalże każde (amerykańskie) przekształcenie. Podkreślę raz jeszcze: Ameryka wysysa świat $\mathrm{z}$ jego bogactwa kulturowego i egzotyki, miksuje je w popkulturową papkę i eksportuje $\mathrm{z}$ powrotem na cały świat, $\mathrm{w}$ tym również do społeczności, z której się wywodziły (przy czym, jak wiemy, większość materialnych przejawów lokalnych kultur jest w ten sposób paradoksalnie przetwarzanych w Chinach, gdzie amerykańskie korporacje mają swoje fabryki).

Tak więc, współcześnie dążenie Ameryki do dominacji nad światem nie oznacza już, iż zmierza się do stworzenia w każdym zakątku świata „miniAmeryk”. Występuje natomiast zjawisko umieszczania różnic kulturowych w ramach amerykańskiej koncepcji świata. Innymi słowy, amerykańska dominacja kulturowa nad światem odbywa się poprzez kultury lokalne i poprzez popularne praktyki kulturowe.

Jednakże, piłka nożna jest jedną z tych praktyk kulturowych, której istnienie w globalnym świecie absolutnie nie pasuje do przedstawionego wyżej sposobu myślenia. Oto bowiem, amerykańskie korporacje nie zdołały uczynić z niej uzależnionej od kultury amerykańskiej dyscypliny sportowej. Ameryka nie zdołała jej „przechwycić”, przekształcić i eksportować na cały świat $\mathrm{w}$ wersji zamerykanizowanej - a próby takie były czynione (na przykład poprzez tworzenie w Ameryce różnych wersji lig piłkarskich, czy takich pozornie "mocarstwowych” klubów, jak na przykład Cosmos New York). Dyscyplina ta w sposób zdecydowany zachowała swój europejski charakter (i bez wątpienia stanowi formę inwazji kulturowej wobec krajów Azji i Afryki, gdzie nie ma dobrze ustanowionej tradycji w tym zakresie). Ciekawe jest również to, że Amerykanie nie zdołali wyeksportować na cały świat takich stricte amerykańskich dyscyplin sportowych, jak baseball czy football, chociaż $w$ tych przypadkach mogą być one postrzegane jako forma amerykańskiego nacjonalizmu. 
Ostatecznie, mogę stwierdzić, że recepcja piłki nożnej w Stanach Zjednoczonych stanowi fascynujący przykład międzykulturowych konfrontacji. Dostarcza też znakomitej egzemplifikacji jednego z paradoksów globalizacji. Potwierdza również tezę Erica Hobsbawma, który twierdzi, iż poprzez cały wiek dwudziesty wszystko co było ważne dla kultury popularnej było albo amerykańskie, albo na marginesie, za wyjątkiem sportu ${ }^{51}$.

\section{BIBLIOGRAFIA}

Anderson E., Inclusive masculinities of university soccer players in the American Midwest, Gender and Education, 2011, 23, 6.

Cassman J.F., Lai D., Football vs. Soccer. American Warfare in an era of unconventional threats, Armed Forces Journal, November 2003.

Collins S., National Sports and Other Myths: The Failure of US Soccer, Soccer and Society, 2006, 7, 2-3.

Collins T., Unexceptional exceptionalism: the origins of American football in a transnational context, Journal of Global History, July 2013, 8, 2.

Crolley L., Hand D., Football and European Identity. Historical Narratives Through the Press, London 2006.

Falk G., Football and American Identity, Binghamption 2005.

Foer F., How Football Explains the World, London 2004.

Gems G.R., Pfister G., Understanding American Sports, Abingdon 2009.

Hase M., Race in Soccer as a Global Sport, [w:] Sports Matters. Race, Recreation and Culture, red. J. Bloom, M.N. Willard, New York 2002.

Honigstein R., Das Roboot. How German Football Reinvented Itself and Conquered the Wolrd, London 2015.

Joyce S., The Top Ten Reasons to Hate Soccer, w: sportowy portal internetowy "bleacher report", http://bleacherreport.com/articles/164778-the-top-ten-reasons to-hate-soc cer/page/2, [dostęp: 29.04.2009].

Lever J., Soccer Madness: Brazil's Passion for the World's Most Popular Sport, Long Grove, 2009.

Lindner A.M., Hawkins D.N., Globalization, Culture Wars, and Attitudes Toward Soccer in America: An Empirical Assessment of How Soccer Explains the World, The Sociological Quarterly, 2012, 53.

Markovits A.S., Hellerman S.L., Offside: Soccer and American Exceptionalism, Princeton 2001.

Markovits A.S., Rensmann L., Gaming the World. How Sports are Reshaping Global Politics and Culture, Woodstock 2010.

Martinez D., Soccer in the USA: 'holding out for a hero'?, Soccer and Society, April 2008, 2, 2.

McCain J., 8 Reasons Why I Hate Soccer, w: sportowy portal internetowy "Go For 2", 30.05.2015; adres internetowy: http:/ / goingfor2.com/8-reasons-why-i-hate-soccer/

Melosik Z., Kryzys męskości w kulturze wspótczesnej, Kraków 2006.

${ }^{51}$ Por. A.S. Markovits, S.L. Hellerman, Offside: Soccer and American Exceptionalism, s. 7. 
Melosik Z., Kultura popularna i tożsamość młodzieży. W niewoli władzy i wolności, Kraków 2013.

Moore S., Why American (rightly) hate the soccer, "The Daily Signal" z 26.06.2014; http:/ / dailysignal.com/2014/06/26/ world-cup-isnt-everyone/

Oriard M., King Football: Sport and Spectacle in the Golden Age of Radio and Newsreels, Movies and Magazines, the Weekly and Daily Press, North Carolina 2001.

Redhead S., Baudrillard, "Ame'rique", and the Hypereal World Cup, [w:] Sport and Postmodern Times, red. G. Rail, Albany 1998.

Risolo D., Soccer Stories: Anecdotes, Oddities, Lore, and Amazing Feats, University of Nebrasca 2010.

Szymanski S., Zimbalist A., National Pastime: How Americans Play Baseball and the Rest of the World, Washington 2005.

Veseth M., Globaloney 2.0: The Crash of 2008 and the Future of Globalization, Plymouth 2010.

Whitsitt S., Soccer: The game America refuses to play, Raritan, Summer 1994, 14, 1.

Winkler J., "Soccer" is a virus invading America. Where are all the rowdt football fans? "The Guardian" z 26.04.2014; adres internetowy: https://www.theguardian.com/comme ntisfree/2014/jun/24/soccer-america-football-fans-world-cup-fever 